\title{
Phase Chemistry and Radionuclide Retention of High Level Radioactive Waste Tank Sludges
}

\author{
By J.L. Krumhansl*, P.V.Brady*, P.C. Zhang*, S. Arthur*, S.K. Hutcherson* and J. \\ Liü. M. Qian ${ }^{\#}$ and H.L. Anderson*
}

Sandia National Laboratories, Albuquerque, NM, 0750-87185

\# Pacific Northwest National Laboratories, Richland WA, 99352

ABSTRACT-

The US Department of Energy (DOE) has millions of gallons of high level nuclear waste stored in underground tanks at Hanford, Washington and Savannah River, South Carolina. These tanks will eventually be emptied and decommissioned. This will leave a residue of sludge adhering to the interior tank surfaces that may contaminate groundwaters with radionuclides and RCRA metals. Experimentation on such sludges is both dangerous and prohibitively expensive so there is a great advantage to developing artificial sludges. The US DOE Environmental Management Science Program (EMSP) has funded a program to investigate the feasibility of developing such materials. The following text reports on the success of this program, and suggests that much of the radioisotope inventory left in a tank will not move out into the surrounding environment. Ultimately, such studies may play a significant role in developing safe and cost effective tank closure strategies.

\section{INTRODUCTION}

Cold War Pu production and purification activities resulted in many millions of gallons of highly radioactive nuclear waste. Most of this material is stored in underground tanks, 177 of which are located on the Hanford Reservation near Richland, Washington and 44 are at the Savannah River Site in South Carolina. The tanks will eventually be emptied and the waste will be vitrified for permanent off-site disposal in a deep underground repository. Currently, the tanks contain three types of materials;

(1) highly caustic saturated sodium nitrate-nitrite-aluminate brines termed "supernate";

(2) solid salts (Na- nitrate, nitrite, hydroxide, aluminate and amorphous Al-phosphates) termed saltcake and which should dissolved in the fluids that eventually will be used to sluice waste from the tanks;

(3) "sludge" - a semi to fully solid masses composed largely of hydrous iron and aluminum oxides along with lesser amounts of other insoluble precipitates that will not dissolve during sluicing operations.

The radioisotope inventory associated with the salt cake and supernate fractions will be largely removed during cleaning operations. However, routine cleaning will still leave significant amounts of sludge adhering to the interior tank surfaces. Removing this material will require exceedingly expensive, specialized technologies, and there is no guarantee that they will achieve acceptable decontamination levels. A lack of success in this endeavor could lead to the even more costly possibility of having to extract the tanks from the ground for off-site disposal. Clearly, minimizing the number tanks receiving such treatments should be a priority.

In the United States performance assessment (PA) calculations are the most common method used to specify remediation levels for polluted sites. In their simplest form such calculations provide a statistical link between the exposure received at a point of compliance some distance removed from the pollution source and the release of material from the source. Essential elements of such calculations are:

(1) the existence of legally defined allowable upper exposure limits that distinguishes between acceptable and unacceptable situations, and

(2) a series of linked subsystem models describing various aspects of how the pollution moves from its source to the point of compliance.

Obviously, being able to estimate the rate at which the pollutant leaves the source is the first step in any successful performance assessment. For HLW tanks this translates to judging whether groundwaters can effectively extract radionuclides from sludge residue. However, experimentation on actual wastes is both hazardous and expensive. Because of this the EMSP initiated research to explore the possibility of gaining the required information using artificial - non radioactive - sludges. The following chapter reviews 


\section{DISCLAIMER}

This report was prepared as an account of work sponsored by an agency of the United States Government. Neither the United States Government nor any agency thereof, nor any of their employees, make any warranty, express or implied, or assumes any legal liability or responsibility for the accuracy, completeness, or usefulness of any information, apparatus, product, or process disclosed, or represents that its use would not infringe privately owned rights. Reference herein to any specific commercial product, process, or service by trade name, trademark, manufacturer, or otherwise does not necessarily constitute or imply its endorsement, recommendation, or favoring by the United States Government or any agency thereof. The views and opinions of authors expressed herein do not necessarily state or reflect those of the United States Government or any agency thereof. 


\section{DISCLAIMER}

Portions of this document may be illegible in electronic image products. Images are produced from the best available original document. 
the status of artificial sludge development and presents preliminary results on the likely course of sludge groundwater interactions.

\section{BACKGROUND}

The contents of HLW storage tanks ultimately are derived from the inradiation of reactor fuel. Although spent reactor fuel results from both the defense and commercial nuclear power industries most of the commercial fuet (at teast in the USA) has not been reprocessed and will probably be disposed of intact. Defense reactors were, however, run to activate uranium and produce plutonium ( $\mathrm{Pu}$ ). Pu recovery required removing the irradiated uranium $(U)$ from the cladding containers and then dissolving the pellets in nitric acid. Various chemical processes were then used to separate and purify $\mathrm{Pu}$. Unfortunately $U$ and $\mathrm{Pu}$ were not the only radioactive components present. The fission process that sustained the nuclear reaction (and provided the neutrons to activate the $U$ ) also produced a host of lighter unstable atoms fission products. Reactor and fuel construction components were also subjected to extreme neutron fluxes and were activated. Finally, activating $U$ produced other heavy nuclei in addition to $\mathrm{Pu}$, principally $\mathrm{Np}$, $\mathrm{Am}$, and $\mathrm{Cm}$. All of these are present in various process waste streams with lesser amounts of Pu and $\mathrm{U}$ that escaped recovery. .

An important part of the picture is that these wastes change their elemental makeup over time because they contain a host of unstable radionucides with differing half lives. Initially ${ }^{137} \mathrm{Cs}$ and ${ }^{90} \mathrm{Sr}$ account for the most of the radioactivity. With half lives of roughly 30 years, however, these drop out of the picture after a few centuries and longer lived radioisotopes assume dominance. It is likely that engineered barriers can be developed that will isolate decommissioned tanks for several centuries (1). At 100 years the chief source of fission product activity still comes from ${ }^{137} \mathrm{Cs}$ and ${ }^{90} \mathrm{Sr}$ while after 1000 years the principal contributors are ${ }^{99} \mathrm{Tc}>{ }^{93} \mathrm{Zr}>{ }^{94} \mathrm{Nb}>{ }^{126} \mathrm{Sn}>{ }^{79} \mathrm{Se},{ }^{155} \mathrm{Cs}>{ }^{151} \mathrm{Sm}>{ }^{129} \mathrm{I}$, with a significant ${ }^{59} \mathrm{Ni}$ contribution from activation of stainless steel (2). Where Zircaloy cladding was some ${ }^{93} \mathrm{Zr}$ may originate from activation processes while the rest originated as a fission product. After 10,000 years the order of the principal fission products is the same except that ${ }^{151} \mathrm{Sm}$ is no longer a player.

Whereas the fission and cladding activation products principally emit beta and gamma radiation the actinide elements initially decay by giving off an alpha particle. Except $\mathrm{Cm}$, all of the actinides have at least one isotope that is long lived enough to be a significant player even after 10,000 years. A seemingly counterintuitive development is that the activities of both ${ }^{234} \mathrm{U}$ and ${ }^{237} \mathrm{~Np}$ actually increase from 1000 to 10,000 years. This, however, can be explained by the decay of relatively short lived ${ }^{238} \mathrm{Pu}$ (half life 92 years) and ${ }^{241} \mathrm{Am}$ (half life 475 years).

Developing chemical processes to obtain pure $\mathrm{Pu}$ was not a triviel undertaking. Most of the development work was done on the Hanford Reservation, in Richland, Washington, USA. The first step was always simply to get the irradiated fuels out of the metal containers (initially $\mathrm{Al}$ and later Zircaloy). The refuse from dissolved containers created large volumes of "cladding wastes". These wastes contained (relatively) small amounts of radioactivity and were not generally strongly acid in character. The irradiated fuel pellets were then dissolved in nitric acid (plus other additives) and various processes were used to recover $\mathrm{Pu}$.

The first process developed for $\mathrm{Pu}$ recovery employed coprecipitation with $\mathrm{BiPO}_{4}$. Two highly radioactive wastes were produced by this activity. About $80 \%$ of the fission products as well as most of the $U$ went to one waste stream that was later reworked for $U$ recovery using a tributyl phosphate (TBP) solvent extraction process. The balance of the fission products, some cladding wastes, and process chemicals from the first Pu purification step went to a second waste stream and is part of the waste inventory consigned to semi-permanent storage in Hanford's underground tanks.

Solvent extraction ultimately won out completely over coprecipitation as a means of recovering $U$ and Pu from irradiated fuel rods. Early developments involved the REDOX process that employed MEBK (methylethylbutyl ketone), used $\mathrm{Al}$ as a salting out agent, and chromate as an oxidant. Later, the PUREX process was developed which used TBP as an extracting agent. During the tenure of the PUREX process the fuel cladding shifted from $\mathrm{Al}$ alloys to Zircaloy. Thus, two waste streams can be defined based on cladding differences. Finally, it should be pointed out that after the early days of the $\mathrm{BiPO}_{4}$ process care was taken to segregate cladding and fuel reprocessing wastes. Thus, in general, there is much more $\mathrm{Al}$ and $\mathrm{Zr}$ in the overall site waste inventory than would be inferred from the waste compositions of the major fission product containing waste streams. 
Even when wastes are subdivided according to the processes responsible for their generation a large number of potential waste streams are involved. This study attempted to identify a waste stream for each process that contained the greatest amount of radioactivity and use that as a basis for sludge synthesis. This automatically deleted cladding wastes from consideration except when, as with the early $\mathrm{BiPO}_{4}$ process, they were mixed with wastes from fuel reprocessing. Table 1 summarizes the results from this effort. For the $\mathrm{BiPO}_{4}$ process the " $1 \mathrm{C} / \mathrm{CW}$ " waste was selected based on tabulations in Kupfer, Table $\mathrm{C}-5$ (3). Redox process waste streams were approximated based on the CWR1 and CWR2 waste streams from Table D2-3 in the same source. Waste solution chemistry from U-recovery operations employing the TBP process was developed from Kupfer (1) using metal wastes from the bismuth phosphate processes (also Table C-5) variously supplemented by input from Agnew (4). PUREX wastes were derived principally from Agnew (4) with supplemental data from other sources $(5,6,7)$. Early parts of this study also used a simplified "NCAW" (neutralized current acid waste) mix developed by Pacific Northwest National Laboratories to simulate late-stage PUREX processes wastes (8).

Prior to storage the acid wastes were rendered strongly caustic with $\mathrm{NaOH}$ and the $\mathrm{NO}_{3}-\mathrm{NO}_{2}{ }^{-}$ratio was adjusted to further minimize corrosion of the mild steel tank liners. It is the premise of this research that the neutralization of the acid wastes was the step which fixed the phase chemistry of the sludges. Thus, the first step in artificial sludge preparation involved adding appropriate amounts of various metal nitrate salts to sodium nitrate/nitrite solutions that was acidified with nitric acid to prevent formation of precipitates. Then, radionuclide surrogates (see below) were added to the solution. The final step in sludge preparation involved making the mixes highly caustic with $\mathrm{NaOH}$ and taking splits for aging at room temperature, $60^{\circ}$, and $90^{\circ} \mathrm{C}$. Higher temperatures were used to accelerate aging and to mimic the fact that many wastes experienced in-tank temperatures near their boiling points for prolonged periods. At various times subsamples of these different aged sludges were washed free of the fluid and analyzed by X-ray diffraction as well as TEM. Chemical analyses of the coexisting fluids and solids were obtained using either DCP-ES (early tests) or later on ICP-MS.

Table 1 - Molar concentrations of significant sludge components in artificial acid wastes.

\begin{tabular}{|l|l|l|l|l|l|l|}
\hline & BiPO4 & $\begin{array}{l}\text { TBP }-U \\
\text { recovery }\end{array}$ & REDOX & PUREX & PUREX & $\begin{array}{l}\text { NCAW -late } \\
\text { PUREX }\end{array}$ \\
\hline & Al Cladding & Al Cladding & AlP>Zr Clad & Al Cladding & Zr Cladding & Al/Zr Clad \\
\hline $\mathrm{Al}$ & $8 \mathrm{E}-2$ & 0 & 1.1 & $8 \mathrm{E}-1$ & 0 & $6 \mathrm{E}-1$ \\
\hline $\mathrm{Fe}$ & $3 \mathrm{E}-2$ & $5 \mathrm{E}-2$ & $5 \mathrm{E}-2$ & $1 \mathrm{E}-1$ & $4 \mathrm{E}-2$ & $1 \mathrm{E}-1$ \\
\hline $\mathrm{Al} / \mathrm{Fe}$ & 2.6 & 0 & 22 & 6.7 & 0 & 0 \\
\hline $\mathrm{Cr}$ & $3 \mathrm{E}-3$ & $3 \mathrm{E}-3$ & $7 \mathrm{E}-2$ & $8 \mathrm{E}-3$ & $3 \mathrm{E}-3$ & $2 \mathrm{E}-2$ \\
\hline $\mathrm{Ni}$ & $2 \mathrm{E}-3$ & $2 \mathrm{E}-3$ & $4 \mathrm{E}-3$ & $1 \mathrm{E}-2$ & $1 \mathrm{E}-3$ & $6 \mathrm{E}-2$ \\
\hline $\mathrm{Zr}$ & $3 \mathrm{E}-4$ & 0 & 0 & 0 & $1 \mathrm{E}-1$ & $4 \mathrm{E}-3$ \\
\hline $\mathrm{Bi}$ & $1 \mathrm{E}-2$ & 0 & 0 & 0 & 0 & 0 \\
\hline $\mathrm{Ca}$ & $2 \mathrm{E}-2$ & $2 \mathrm{E}-2$ & 0 & $6 \mathrm{E}-2$ & $2 \mathrm{E}-2$ & 0 \\
\hline $\mathrm{Si}$ & $6 \mathrm{E}-2$ & $4 \mathrm{E}-3$ & $4 \mathrm{E}-2$ & $5 \mathrm{E}-2$ & 0 & $8 \mathrm{E}-3$ \\
\hline $\mathrm{F}$ & $2 \mathrm{E}-1$ & 0 & 0 & 0 & $8 \mathrm{E}-1$ & $1 \mathrm{E}-1$ \\
\hline $\mathrm{P}$ & $2 \mathrm{E}-2$ & $1 \mathrm{E}-1$ & 0 & $2 \mathrm{E}-2$ & 0 & 0 \\
\hline $\mathrm{Pb}$ & $4 \mathrm{E}-4$ & $1 \mathrm{E}-4$ & $1 \mathrm{E}-2$ & $1 \mathrm{E}-3$ & 0 & 0 \\
\hline $\mathrm{Mn}$ & $7 \mathrm{E}-3$ & 0 & 0 & $3 \mathrm{E}-2$ & 0 & 0 \\
\hline $\mathrm{SO}{ }_{4}{ }^{-1}$ & $5 \mathrm{E}-2$ & $2 \mathrm{E}-1$ & $2 \mathrm{E}-2$ & $2 \mathrm{E}-2$ & $2 \mathrm{E}-2$ & $1 \mathrm{E}-1$ \\
\hline $\mathrm{Cd}$ & $1 \mathrm{E}-5$ & $8 \mathrm{E}-6$ & 0 & $1 \mathrm{E}-3$ & $1 \mathrm{E}-3$ & 0 \\
\hline
\end{tabular}

The choice of radionuclide surrogates merits some discussion. The immediate hazard presented by HLW fluids arises from short-lived radioisotopes such as ${ }^{154} \mathrm{Eu},{ }^{144} \mathrm{Ce},{ }^{137} \mathrm{Cs},{ }^{106} \mathrm{Ru},{ }^{90} \mathrm{Sr}$ and ${ }^{60} \mathrm{Co}$. The release of these radioisotopes from a leaking tank may be of considerable importance with regard to tracking short-term plume migration as well as understanding the surface exchange characteristics of various sludge and soil components. However, they do not present a long-term a hazard to the environment since they will probably decay before a decommissioned tank is breached and would not last long enough to travel far in most slow-moving ground water systems. 
Instead, low activity-long lived radioisotopes are typically identified by performance assessments as presenting the greatest hazard. As outlined above, these are relatively few in number: ${ }^{99} \mathrm{Tc}>{ }^{63} \mathrm{Ni}>{ }^{93} \mathrm{Zr}$ $>{ }^{94} \mathrm{Nb}>{ }^{126} \mathrm{Sn}>{ }^{79} \mathrm{Se},{ }^{135} \mathrm{Cs}>{ }^{151} \mathrm{Sm}>>{ }^{129} \mathrm{I}$. Except for ${ }^{99} \mathrm{Tc}$, all of these elements have non-radioactive isotopes that can be substituted for radioisotopes in order to study their affinity for artificial sludges. It is also fortunate that in oxidizing environments $\mathrm{ReO}_{4}{ }_{4}$ is a reasonable substitute for $\mathrm{TcO}_{4}{ }^{-}$.

Actinides are more problematic. Uranium (depleted) and thorium can be handled without specialized hot cell facilities but a prohibitive administrative burden still exists even though their heavy metal toxicity greatly outweighs any danger posed by radioactivity. Still, considerable insight into the behavior of $\mathrm{Pu}$ might eventually be gained using a combination of U(VI) and Th(IV). The pentavalent actinides [(PU(V) and $\mathrm{Np}(\mathrm{V})$ ] may be important in a number of environments but no good nonradioactive analogues exists. However, americium and curium (both dominantly +3 valence) have good non-radioactive surrogates in the rare earth elements.

Finally, HLW fluids may contain a number of non-radioactive metals that are of concern for their chemical toxicity - notably $\mathrm{Pb}, \mathrm{Cd}$, and $\mathrm{Cr}$. In all, the list of "surrogates" included $\mathrm{Pb}, \mathrm{Cd}, \mathrm{Cs}, \mathrm{Ba}$ (for $\mathrm{Ra}$ ), $\mathrm{Sr}, \mathrm{Nd}$ (for $\mathrm{Am}, \mathrm{Sm}$, and $\mathrm{Cm}$ ), $\mathrm{CrO}_{4}{ }^{-}, \mathrm{Se}, \mathrm{ReO}_{4}^{-}$(for $\mathrm{TcO}_{4}^{-}$) and $\mathrm{Co}$. $\mathrm{Ni}$ is an integral part of the recipe of all the synthetic sludges and so it was not included in the list of surrogates. $\mathrm{Nb}$ and $\mathrm{Sn}$ were not included because their extreme low solubility in neutral to basic oxidizing solutions (9) allows one to a priori predict they will not be mobilized into the groundwater. In general, depending on the experiment, these surrogates were added so that the artifical sludge solutions would contain 20 to $100 \mathrm{ppm}$ prior to precipitating the sludges. These concentrations are higher than they would occur in actual wastes but this was necessary so that they would be detectable in various post-test analyses.

\section{SLUDGE PHASE CHEMISTRY:}

The first issue needing resolution is the degree to which the major phase chemistry of the artificial sludges resembles that found in actual tanks. Only limited data is available on actual tank contents (10) and not all of it refers to phases that would survive tank cleaning procedures and remain in the sludge. Further, most of this data has been gained by transmission electron mitroscopy which tends to bias the study toward recognizable relatively well crystallized materials that may, in fact, only be present in minor amounts. Still the e tabulation of phases observed from the tanks is a useful reference point from which to judge success in fabricating artificial sludges. This list includes:

1. The principal Al-bearing phases likely to survive waste retrieval activities are boehmite (typical of high temperature sludges) and gibbsite (lower temperature sludges).

2. Amorphous and crystalline aluminosilicates are also found at Hanford, particularly where diatomaceous earth was added to retard leakage. At Savannah River these same materials make up a significant amount of the heel in the tank bottoms (10) since zeolites used in Cs recovery were dumped in the tanks and subsequently altered to natrodavyne (a member of the cancrinite-family of zeolites).

3. Iron occurs principally as amorphous iron hydroxide

4. $\mathrm{Bi}$ occurs as a desecrate $\mathrm{Bi}_{2} \mathrm{O}_{3}$, as $\mathrm{BiPO}_{4}$ and as an iron bismuth silicate hydroxide that yields weak electron diffraction patterns and hence is more crystalline than the amorphous iron oxide.

5. $\mathrm{Cr}$ is found associated with the both $\mathrm{Al}$ and Fe oxide - hydroxide components.

6. $\mathrm{Ca}$ and $\mathrm{P}$ occur as hydroxyapatite.

7. Other minor phases include Bi-chromate, $\mathrm{Fe}-\mathrm{Bi}$-phosphates, amorphous descrete $\mathrm{Cr}(\mathrm{OH})_{3}, \mathrm{Fe}-\mathrm{Mn}$ oxides, La-phosphate, $(\mathrm{Fe}, \mathrm{Mn})\left(\mathrm{MnO}_{4}\right)_{2}$ and, of course, the occasional $\mathrm{U}$ or Pu containing oxide.

X-ray diffraction traces of synthetic sludges (Fig. 1) typically have a complex structure with sharp diffraction maxima for the few well crystallized components superimposed on a single broad hump characteristic of the amorphous (largely $\mathrm{Fe}$ ) components in the sludge. The sludges were also characterized by transmission electron microscopy (TEM) supplemented by energy dispersive analysis and selected area electron diffraction. This examination revealed the presence of a number of minor phases as well as indicated how minor components in the sludges partitioned among the major sludge phases (Table 2). 


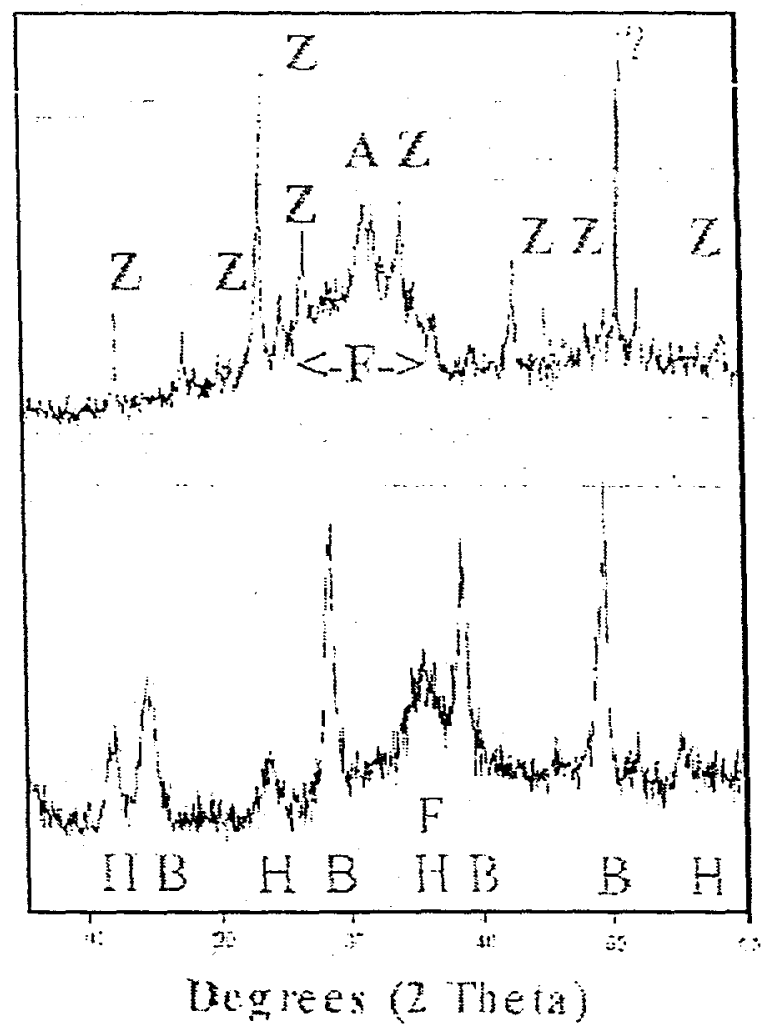

Fig. 1 X-ray diffraction patterns of synthetic $\mathrm{BiPO}_{4}$ (top) and NCAW-PUREX (bottom) sludges aged at $90^{\circ} \mathrm{C}$. $\mathrm{B}=$ boehmite, $\mathrm{H}=\mathrm{a}$ Ni-hydrotalcite resembling green rust in structure, $\mathrm{F}=$ ferrihydrite, $\mathrm{Z}=\mathrm{a}$ cancrinite group zeolite, $\mathrm{A}=$ apatite.

Of greatest interest are whether the main iron and aluminum containing phases in the sludge resemble those in the actual sludges. Figures 2 and 3 present comparisons of the hydrous iron oxides found in real and artificial sludges. In both cases the morphologies of the artificial sludge particles are a good match for the real thing. However, in the case of the Bi-rich sludge electron diffraction shows that the actual tank sludge is poorly crystalline while the artificial material is still completely amorphous. The lack of crystallinity in the iron oxide phase of heated-aged sludges is of particular interest since in other systems ferrihydrite often alters to goethite (or other crystalline phases) in a matter of days (11). However, Al in particular has been noted to retard the crystallization of such materials. Entries in Table II for FeOOH(xl?) show that even if $\mathrm{Al}$ is absent enough other elements are incorporated into the ferrihydrite to retard its inversion to more crystalline phases.

The correspondence with the Al-bearing compounds is more complex. Both real and artificial sludges are rich in boehmite $(\mathrm{AlO}(\mathrm{OH}))$ but the morphologies are significantly different (Fig. 4). The artificial materials do not seem to form the large crystals that exist in real sludges. It is likely that this reflects the longer aging in the real sludges, and, unlike the experiments, the supernate solutions in the tanks often underwent extreme evaporative concentration and achieved very high ionic strengths. A consequence of this difference is that artificial sludges might have somewhat greater exchange capacities than the real sludges. Zeolites are the other Al-containing phase that are occasionally abundant in sludges. To the degree that comparisons are possible, it appears that the real and artificial materials have similar morphologies (Fig. 5). 
Table 2 - Phases identified in artificial sludges

\begin{tabular}{|c|c|c|c|}
\hline Data & Waste Stream & $\mathrm{X}$-ray detected phases & TEM detected phases with elements by EDS \\
\hline $\begin{array}{l}23^{\circ} \mathrm{C} \\
169 \text { Days }\end{array}$ & $\begin{array}{l}\mathrm{BiPO}_{4} \text { process - } \\
(1 \mathrm{C} / \mathrm{CW})\end{array}$ & $\begin{array}{l}\text { Apatite } \\
\text { 2-line Ferrihydrite }\end{array}$ & $\begin{array}{l}\text { Apatite } \mathrm{Ca}>\mathrm{Si}>\mathrm{P}>\mathrm{Al}, \mathrm{Fe}>\mathrm{Bi} \\
\mathrm{Bi}-\mathrm{Fe} \text {-oxide } \mathrm{Fe}, \mathrm{Ca}, \mathrm{Si}>\mathrm{Bi}>\mathrm{P}>\mathrm{Al}>>\mathrm{Mn}>\mathrm{Cr} \\
\text { Zeolite } \mathrm{Si}>\mathrm{Al}>\mathrm{Ca}>\mathrm{Na}>>\mathrm{Fe}>\mathrm{Cd}\end{array}$ \\
\hline $\begin{array}{l}90^{\circ} \mathrm{C} \\
169 \text { Days }\end{array}$ & $\begin{array}{l}\mathrm{BiPO}_{4} \text { process } \\
(1 \mathrm{C} / \mathrm{CW})\end{array}$ & $\begin{array}{l}\text { Apatite } \\
\text { Zeolite }\end{array}$ & $\begin{array}{l}\text { Apatite } \mathrm{Ca}>\mathrm{P}>>\mathrm{Na}>\mathrm{Bi}>\mathrm{Pb}, \mathrm{Trace} \mathrm{Mn}, \mathrm{Fe} \\
\text { Zeolite } \mathrm{Al}, \mathrm{Si}>>\mathrm{Na}, \mathrm{Bi}, \mathrm{Ca}, \mathrm{Fe}>\mathrm{Mn}, \mathrm{P},>\mathrm{Cr}, \\
\text { Trace } \mathrm{Cr}, \mathrm{Ni}, \mathrm{Pb} \\
\mathrm{Bi} \text { metal } \mathrm{Bi}>>\mathrm{Na} \text {, Trace } \mathrm{P} \\
\mathrm{Fe}-\mathrm{Bi} \text { oxide } \mathrm{Fe}, \mathrm{Bi}>>\mathrm{Mn}, \mathrm{Si},>\mathrm{Al}, \mathrm{P}, \mathrm{Ca}, \mathrm{Na}, \\
\mathrm{Trace} \mathrm{Pb} \\
\mathrm{CaSO}_{4} \mathrm{Ca}, \mathrm{S}>>\mathrm{Na} \\
\mathrm{ZrO}_{2}, \mathrm{Zr}>>\mathrm{Na} \\
\mathrm{Goethite}_{\mathrm{Fe}}>>\mathrm{Na} \\
\text { Hematite, } \mathrm{Fe} \gg>\mathrm{Na}\end{array}$ \\
\hline $\begin{array}{l}23^{\circ} \mathrm{C} \\
169 \text { Days }\end{array}$ & $\begin{array}{l}\text { Tri-Butyl- } \\
\text { Phosphate - } \\
\text { U recovery }\end{array}$ & $\begin{array}{l}\text { Apatite } \\
\text { 2-line Ferrihydrite }\end{array}$ & $\begin{array}{l}\text { Apatite, } \mathrm{Ca}, \mathrm{P}>>\mathrm{Fe} \gg>\mathrm{Pb}, \mathrm{Cr}, \mathrm{Na} \\
\mathrm{FeOOOH}(\mathrm{xl} \text { ?) } \mathrm{Fe}>>\mathrm{Al}, \mathrm{Si}, \mathrm{P}, \mathrm{Pb}, \mathrm{Ca}, \mathrm{Cr}\end{array}$ \\
\hline $\begin{array}{l}90^{\circ} \mathrm{C} \\
169 \text { Days }\end{array}$ & $\begin{array}{l}\text { Tri-Butyl- } \\
\text { Phosphate - } \\
\text { U recovery }\end{array}$ & $\begin{array}{l}\text { Apatite } \\
\text { 2-line Ferrihydrite }\end{array}$ & $\begin{array}{l}\mathrm{FeOOH}(\mathrm{xl} \text { ? }), \mathrm{Fe}>>\mathrm{Ca}>\mathrm{Si}>\mathrm{Ni}, \mathrm{Pb} \\
\text { apatite, } \mathrm{Ca}, \mathrm{P}>\mathrm{Fe}, \mathrm{Na} \\
\mathrm{PbO} \mathrm{Pb}>>\mathrm{Fe}>\mathrm{Ca}\end{array}$ \\
\hline $\begin{array}{l}23^{\circ} \mathrm{C} \\
169 \text { Days }\end{array}$ & REDOX & $\begin{array}{l}\text { Boehmite, } \\
\text { Gibbsite } \\
\text { Hematite (trace) }\end{array}$ & $\begin{array}{l}\text { Boehmite, } \mathrm{Al}>\mathrm{Si}>\mathrm{Cr}, \mathrm{Fe}>\mathrm{Ca} \\
\text { Gibbsite, } \mathrm{Na}>>\mathrm{Al} \\
\text { (Fe, } \mathrm{Cr}, \mathrm{Al}, \mathrm{Si}) \mathrm{OOH}(\mathrm{xl} \text { ?) } \mathrm{Al}>\mathrm{Fe}, \mathrm{Cr}>\mathrm{Si}>\mathrm{Ca} \text {, } \\
\text { Trace } \mathrm{Pb}, \mathrm{Ni} \\
\text { Portlandite } \mathrm{Ca}>>\mathrm{Na} \\
\text { Hematite } \mathrm{Fe}>>\mathrm{Si}, \mathrm{Ca}>\mathrm{Pb}, \mathrm{Na}>\mathrm{Ni}\end{array}$ \\
\hline $\begin{array}{l}90^{\circ} \mathrm{C} \\
169 \text { Days }\end{array}$ & REDOX & $\begin{array}{l}\text { Zeolite, } \\
\text { Boehmite, } \\
\text { Hematite(trace), } \\
\text { Goethite(trace) } \\
\end{array}$ & $\begin{array}{l}\text { Zeolite, } \mathrm{Al}>\mathrm{Si}>>\mathrm{Ca}, \mathrm{Fe}, \mathrm{Si}>>\mathrm{Cr} \\
\text { boehmite, } \mathrm{Al}>>\mathrm{Si}, \mathrm{Fe}, \mathrm{Cr}>\mathrm{Ca}>\mathrm{Na}> \\
\text { FeOOH(xl?) Al,Fe>Cr}>\mathrm{Na}, \mathrm{Pb}, \mathrm{Si}, \mathrm{P}>\mathrm{Ti}>\mathrm{Ni}\end{array}$ \\
\hline $\begin{array}{l}90^{\circ} \mathrm{C} \\
169 \text { Days }\end{array}$ & $\begin{array}{l}\text { PUREX - Al } \\
\text { Cladding }\end{array}$ & $\begin{array}{l}\text { Boehmite, } \\
\text { Zeolite, } \\
\text { Hematite }\end{array}$ & $\begin{array}{l}\text { Boehmite No EDS taken } \\
\text { Zeolite (good } \mathrm{xl} \text { ) Al>Si }>\mathrm{Na}>>\mathrm{Fe}, \mathrm{Ca} \\
\text { Apatite, No EDS tanken } \\
\mathrm{FeOOH}(\mathrm{xl} \text { ?) } \mathrm{Fe}>>\mathrm{Al}>\mathrm{Bi}>\mathrm{Mn}\end{array}$ \\
\hline $\begin{array}{l}23^{\circ} \mathrm{C} \\
169 \text { Days }\end{array}$ & $\begin{array}{l}\text { PUREX }-\overline{\mathrm{Zr}} \\
\text { Cladding }\end{array}$ & $\begin{array}{l}\mathrm{Na}_{3} \mathrm{ZrF}_{7}, \mathrm{NaFe}_{3}\left(\mathrm{SO}_{4}\right)_{2} \\
\mathrm{NaNO}_{3} \\
\mathrm{Ca}_{5}(\mathrm{SiO} 4)_{2}(\mathrm{OH}, \mathrm{F})_{2}\end{array}$ & $\begin{array}{l}\text { Fluorite, } \mathrm{Ca}, \mathrm{F}>\mathrm{Na}, \mathrm{Zr}, \mathrm{Fe}>\mathrm{Cr}, \mathrm{Si} \\
\mathrm{NaFeO}_{2} \mathrm{Fe}, \mathrm{Na}>>\mathrm{Zr}, \mathrm{Ca}, \mathrm{Cr}, \mathrm{Ni} \\
\mathrm{Na}_{2} \mathrm{FeF}_{6} \mathrm{Na}, \mathrm{F}, \mathrm{Fe}>\mathrm{Ca}>\mathrm{Cr}, \mathrm{Zr} \\
\mathrm{Na}_{3} \mathrm{ZrF}_{7} \mathrm{Na}, \mathrm{Zr}, \mathrm{F} \gg>>\mathrm{Ca}, \mathrm{Cr}, \mathrm{Fe}, \mathrm{Si}\end{array}$ \\
\hline $\begin{array}{l}90^{\circ} \mathrm{C} \\
169 \text { Days }\end{array}$ & $\begin{array}{l}\text { PUREX }-Z \text { F } \\
\text { Cladding }\end{array}$ & $\begin{array}{l}\text { Mostly Unknown, } \\
\text { 2-line Ferrihydrite }\end{array}$ & $\begin{array}{l}\text { Fluorite, } \mathrm{Ca}, \mathrm{F}, \mathrm{Trace} \mathrm{Na}, \mathrm{P}, \mathrm{Pb} \\
\mathrm{FeOOOH}(\mathrm{xl} ? \text { ?) } \mathrm{Fe}>\mathrm{Ca}, \mathrm{F}, \mathrm{P}, \mathrm{Si}, \mathrm{Al}, \mathrm{Na}>\mathrm{Pb} \text {, } \\
\mathrm{Ni}, \mathrm{Zn}, \mathrm{Cs} \\
\mathrm{ZrO}_{2} \mathrm{Zr}>>\mathrm{Ca}, \mathrm{Fe}, \mathrm{Si}, \mathrm{Na}>\mathrm{Pb}\end{array}$ \\
\hline $\begin{array}{l}90^{\circ} \mathrm{C} \\
266 \text { Days }\end{array}$ & $\begin{array}{l}\text { NCAW: } \\
\text { generic late } \\
\text { stage PUREX }\end{array}$ & $\begin{array}{l}\text { Boehmite } \\
\text { Fe-Ni-Hydrotalcite }\end{array}$ & $\begin{array}{l}\text { Boehmite } \mathrm{Al}>>\mathrm{Fe}>>\mathrm{Ni}>\mathrm{Cr}, \mathrm{Ca}, \mathrm{P}, \mathrm{Ti} \\
\text { Fe-Ni-hydrotalcite } \mathrm{Al}>\mathrm{Ni}>\mathrm{Fe}>>\mathrm{Cr}, \mathrm{Ti}, \mathrm{Ca} \\
\text { Portlandite, } \mathrm{Ca}\end{array}$ \\
\hline
\end{tabular}



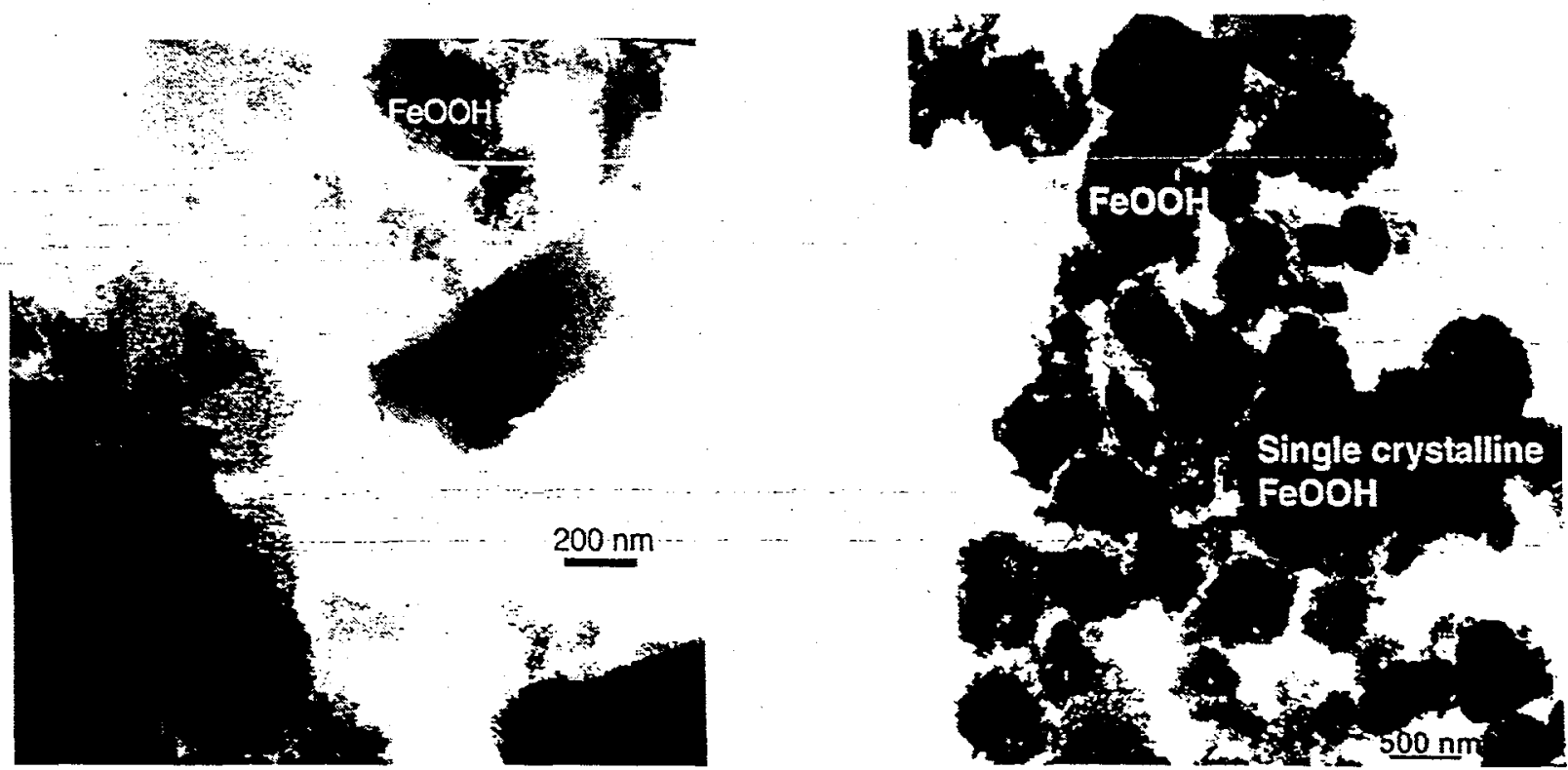

Fig. 2. Comparison of hydrous iron oxides from synthetic sludges aged at $90^{\circ} \mathrm{C}$ for 169 days and actual sludge from tank C-107.

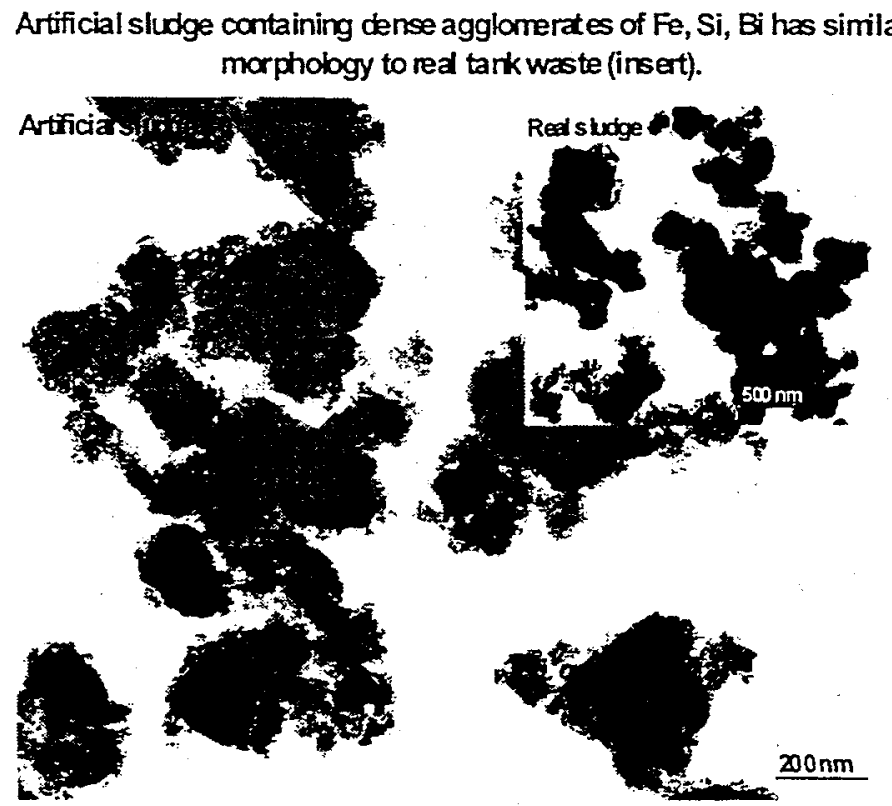

JUnLLU PWWL, Fictterd, WA

Fig. 3 Comparison of hydrous iron oxides rich in $\mathrm{Bi}$ and $\mathrm{Si}$ in artificial sludges and actual tank sludge (inset) 

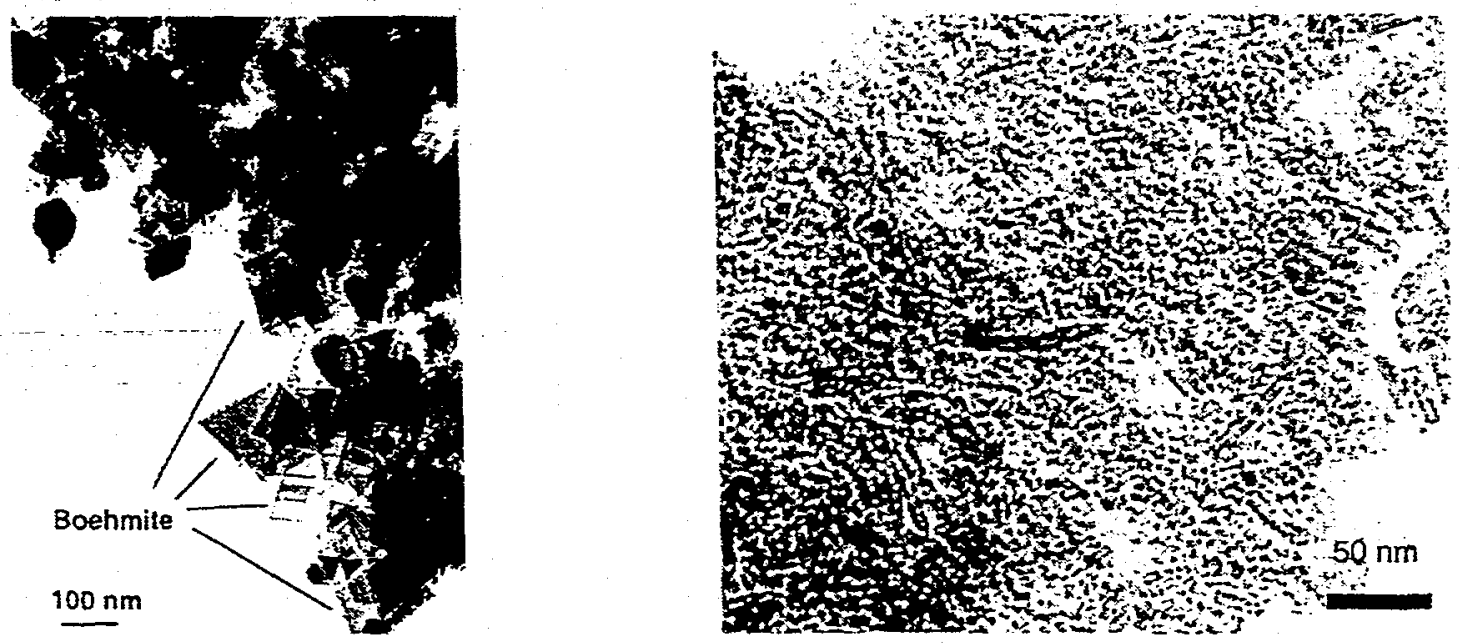

Fig. 4 Comparison of boehmite formed in tanks (left) and artificial sludges (right)

Auninosilicates in red tark weste and in artificial studge have similar morphologies

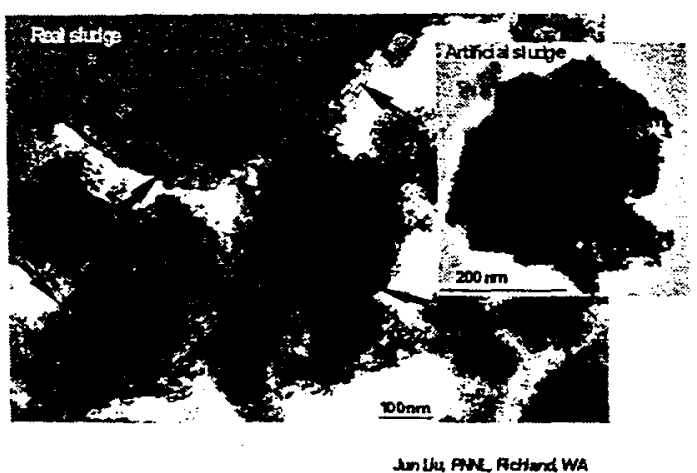

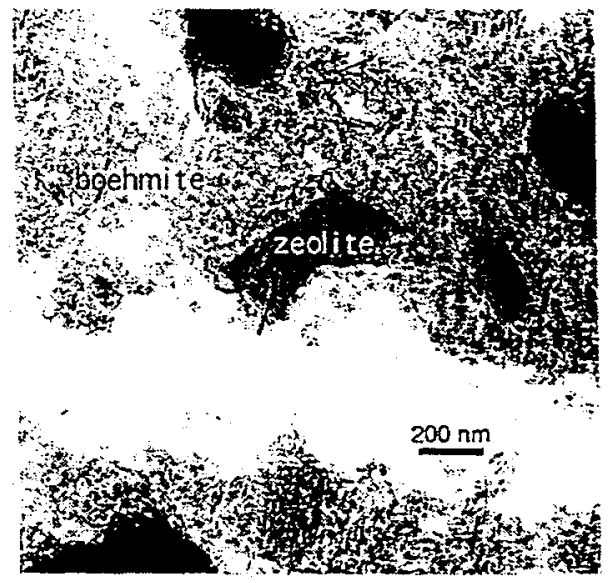

Fig. 5 Comparison of zeolitic materials from tanks and artificial sludge (left, inset). Artificial sludges may also contain coarsely crystalline zeolitic materials along with fine-grained boehmite (right)

\section{SLUDGE-SUPERNATE INTERACTIONS:}

Two sets of experiments were carried out to judge the impact of sludge precipitation on the composition of the coexisting supernate. The objective of these experiments was to assess which elements were initially partitioned into the solids (and would be available for later release from sludges). The basic sludge recipes enumerated in Table 1 were employed and doped with surrogates as described above. The day after the sludges were precipitated, and prior to any heating, the supernates were filtered and analyzed by direct current plasma (DCP) emission spectroscopy. Accounting for dilution, this provided surrogate detection limits in the low ppm range. This was sufficiently sensitivity to confirm that the those surrogates expected to be insoluble in strong base (9) were quantitatively removed from the liquid supernate. Rather surprisingly, small but detectable, decreases were also observed in elements existing as anions $\left(\mathrm{ReO}_{4}{ }^{\circ}\right.$ and $\mathrm{SeO}_{4}{ }^{3}$ ) that neither sorbed or formed insoluble compounds. Further, these losses were only observed in the high aluminum REDOX and Al-PUREX sludges. Toward the end of the FY an opportunity arose to depart 
from the normal research approach and confirm these findings with $\mathrm{TcO}_{4}^{-}$rather than $\mathrm{ReO}_{4}{ }^{-}$(Table 3). As with $\mathrm{ReO}_{4}^{-}$, the Al-rich sludges also sorbed $\mathrm{TcO}_{4}^{-}$, though unlike $\mathrm{ReO}_{4}^{-}$more than half of the $\mathrm{TcO}_{4}^{-}$was released by heating the sludge to $90^{\circ} \mathrm{C}$ overnight.

Table 3 - Decreases in anionic components during preparation of artificial sludges

\begin{tabular}{|l|l|l|l|}
\hline Sludge Type & Re & Tc & Se \\
\hline Al-PUREX & 40 to $29 \mathrm{ppm}$ & 1 to $0.6 \mathrm{ppm}$ & 40 to $26 \mathrm{ppm}$ \\
\hline REDOX & 40 to $27 \mathrm{ppm}$ & 1 to $0.8 \mathrm{ppm}$ & 40 to $31 \mathrm{ppm}$ \\
\hline
\end{tabular}

More detailed studies involving $\mathrm{ReO}_{4}^{-}$sorption onto boehmite in low ionic strength solutions (Fig. 6 ) identified the mechanism responsible for removing anionic components during sludge precipitation (Table 3 ). $\mathrm{ReO}_{4}{ }^{-}$sorption is not significant above $\mathrm{pH} 9$, and certainly would not occur in the $\mathrm{pH} 11-12$ solutions in contact with the artificial sludges. However, most of the boehmite in the artificial sludges would have precipitated between $\mathrm{pH} 3$ and $\mathrm{pH} 8$. In this interval $\mathrm{ReO}_{4}{ }^{-}$(and other anions) would have sorbed on the freshly forming surfaces and then become occluded by further growth of the boehmite crystals. Anions sorbed in this manner would not be available to desorb at the higher $\mathrm{pH}$ of the final sludge solutions, thus resulting in the effects noted in Table 3 . However, Ostwald ripening may cause boehmite grains to grow and recrystallize, thus releasing the anions in a high $\mathrm{pH}$ environment. This could account for the Tc release noted in the heated artifical sludges. Apparently $\mathrm{SeO}_{4}{ }^{2}$ and $\mathrm{ReO}_{4}{ }^{-}$are more strongly held since they were not released like the Tc.

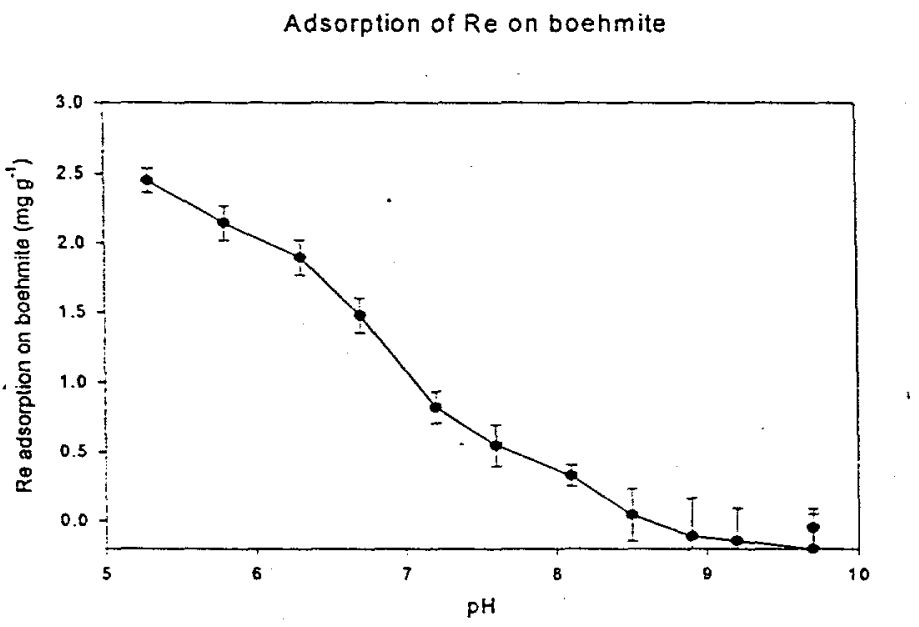

Fig. $6 \mathrm{ReO}_{4}{ }^{\circ} \mathrm{Kd}$ values for sorption onto boehmite as a function of $\mathrm{pH}$ in $0.0005 \mathrm{M} \mathrm{NaNO}_{3}$ solutions

These experiments only lasted two days and there was a suggestion that short term recrystallization might impact surrogate retention. Thus, longer two week experiments were carried out at room temperature and $90^{\circ} \mathrm{C}$, and this time the supernate fluids were analyzed by ICPMS (Table 4 ). Several trends are evident in this data. In many cases chromate is much higher than the level that was initially added as a surrogate. The explanation for this lies in the highly oxidizing properties of the supernate fluids. These apparently transformed trivalent chromium in the basic sludge recipe to soluble chromate, a "surrogate". The remaining two anomalous high values probably represent analytic errors. Co, $\mathrm{Sr}, \mathrm{Cd}$ and $\mathrm{Nd}$ were universally scavenged from solution while the scavenging of $\mathrm{Sr}$ was spotty and that of $\mathrm{Ba}$ relatively poor. These analyses also indicated some scavenging of $\mathrm{Re}$ and $\mathrm{Se}$, but not to the extent observed in the short term experiments (Table 3). Further, this time no preference was evident for the high Al sludges. 
Table - 4 Analysis of post-precipitation fluids after sludges were aged for two weeks (PPM)

\begin{tabular}{|l|l|l|l|l|l|}
\hline Element & BiPO4 & TBP & REDOX & PUREX-Al & PUREX-Zr \\
\hline AVFe-molar & 1.1 & 0 & 15.7 & 12.2 & 0 \\
\hline $25^{\circ}$ C Expts. & & & & & \\
\hline $\begin{array}{l}\text { Initial Conc. } \\
\text { All Surrogates }\end{array}$ & $87 \mathrm{ppm}$ & $85 \mathrm{ppm}$ & $84 \mathrm{ppm}$ & $79 \mathrm{ppm}$ & $88 \mathrm{ppm}$ \\
\hline $\mathrm{Cr}$ & 77 & & & & \\
\hline $\mathrm{Co}$ & $<0.40$ & $<0.40$ & $108^{*}$ & 9.9 & 79 \\
\hline $\mathrm{Sr}$ & 0.74 & $<0.30$ & $<0.30$ & $<0.20$ \\
\hline $\mathrm{Cd}$ & $<0.40$ & 1.050 & $<0.20$ & $<0.20$ & 0.22 \\
\hline $\mathrm{Ba}$ & 7.94 & $<0.40$ & $<0.20$ & $<0.20$ & $<0.20$ \\
\hline $\mathrm{Nd}$ & $<0.40$ & 4.67 & 60.04 & 4.36 & 5.69 \\
\hline $\mathrm{Pb}$ & $<0.30$ & 00.40 & $<0.20$ & $<0.20$ & $<0.20$ \\
\hline $\mathrm{Se}$ & $73(-16 \%)$ & $65(-15 \%)$ & $66(-21 \%)$ & $53(-33 \%)$ & $71(-19 \%)$ \\
\hline $\mathrm{Re}$ & $81(-6.8 \%)$ & $70(-16 \%)$ & $71(-16 \%)$ & $67(-15)$ & $74(-16 \%)$ \\
\hline $\mathrm{Cs}$ & $75(14 \%)$ & $67(-15 \%)$ & $97 *$ & $72(-8.9 \%)$ & $79(-10 \%)$ \\
\hline $90^{\circ} \mathrm{C}$ & & & & & \\
\hline $\mathrm{Al} \mathrm{Fe}-$ molar $\#$ & 2.0 & 0 & 9.1 & 2.9 & 0 \\
\hline $\mathrm{Cr}$ & $179^{*}$ & $141^{*}$ & $691^{*}$ & $157^{*}$ & $163^{*}$ \\
\hline $\mathrm{Co}$ & 0.63 & $<0.40$ & $<0.40$ & $<0.30$ & $<0.30$ \\
\hline $\mathrm{Sr}$ & 0.88 & 0.86 & $<0.40$ & $<0.20$ & $<0.20$ \\
\hline $\mathrm{Cd}$ & $<0.40$ & $<0.40$ & $<0.40$ & $<0.20$ & $<0.20$ \\
\hline $\mathrm{Ba}$ & 8.2 & 3.2 & 7.1 & 5.5 & $<0.20$ \\
\hline $\mathrm{Nd}$ & $<0.40$ & $<0.40$ & $<0.40$ & $<0.20$ & $<0.20$ \\
\hline $\mathrm{Pb}$ & $<0.30$ & 0.80 & 1.88 & $<0.20$ & $<0.20$ \\
\hline $\mathrm{Se}$ & $72(-17 \%)$ & $64(-25 \%)$ & $65(-23 \%)$ & $58(-26.6 \%)$ & $72(-18 \%)$ \\
\hline $\mathrm{Re}$ & $83(-4.6 \%)$ & $72(-15 \%)$ & $77(-8.4 \%)$ & $69(-13 \%)$ & $80(-9.1 \%)$ \\
\hline $\mathrm{Cs}$ & $82(-5.7 \%)$ & $77(-9.4 \%)$ & $75(-11 \%)$ & $72(-8.9 \%)$ & $89^{*}$ \\
\hline
\end{tabular}

* Concentrations exceed amount added initially

$\#$ Based on post-test sludge analyses, not as-mixed proportions

The absence of a clear correlation between $\mathrm{Al}$ content and anion sorption suggests that in these experiments the ubiquitous hydrous iron oxides dominated sorption-desorption process. The shift in behavior can be understood in light of the fact that the surface properties of both $\mathrm{Fe}$ and $\mathrm{Al}$ oxides are quite variable. Depending on the particular oxide species the zero point of charge (e.g. the pH below which the surface is positively charged and hence sorbs anions) for Al oxides and hydroxides ranges from $\mathrm{pH} 9$ to $\mathrm{pH}$ 5 while for Fe oxides and hydroxides the range is $\mathrm{pH} 8.5$ to $\mathrm{pH} 6.7$ (12). Thus, the characteristics of the oxides that happen to form, or evolve, in a particular experiment will determine which (if any) hydrous oxide plays a dominant role in anion sorption.

In those cases where Fe-hydrous oxides dominate it is possible to employ geochemical models to predict the relative sorption of different components (Fig. 7). Results of this modeling clearly reflect several trends observed in Table 4. As the pH becomes highly caustic it is apparent that $\mathrm{Ba}$ should, and did, remain in solution to a greater degree that $\mathrm{Sr}$. As expected, $\mathrm{Se}$ (as $\mathrm{SeO}_{4}{ }^{=}$due to the oxidizing nature of the fluids) desorbs as the $\mathrm{pH}$ increases and should be predominantly in solution at the highest $\mathrm{pH} . \mathrm{Pb}$ and Eu (for Nd) are strongly removed from solution. It is not clear why the TBP and REDOX fluids still contain some $\mathrm{Pb}$ when the other do not. These fluids don't appear to share any component in anomalous amounts that would account for this behavior (Table 1). Co is also strongly removed over most of the $\mathrm{pH}$ range but would seem to be returning to solution at the end of the titration. The absence of high Co values in Table 4 suggests that most of the sorbed $C o$ inventory resides inside ferrihydrite masses rather on the surfaces where it could be released to strongly caustic solutions. 


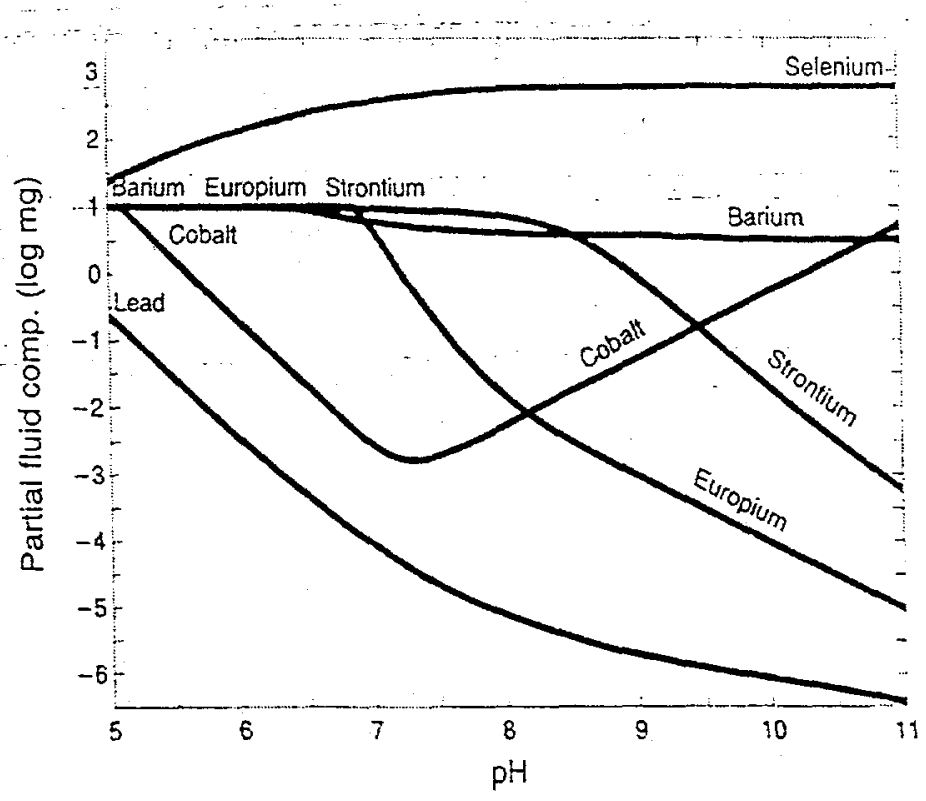

Fig.7 Theoretical sorption on hydrous iron computed using the REACT code (13)

The final stage of this study was directed at observing surrogate releases as the $\mathrm{pH}$ and ionic strength fell in a manner that mimicked the entry of normal groundwater and displacement of indigenous sludge pore fluids (e.g. "supernates"). This was accomplished by first dialyzing the sludge suspension to remove the residual supernate solution and then suspending the sludge directly in deionized and titrating the $\mathrm{pH}$ downward with dilute nitric acid. The solids were then recovered on a filter, washed with fresh deionized water, and leached into solution with a mix of concentrated nitric plus hydrochloric acids. Since it was impossible to weight the amount of solid caught in the filters the data are tabulated based on the assumption that all the iron in the initial recipe was precipitated and remained in the solid until the sample was removed with acid. From the initial recipe an initial surrogate : Fe ratio was calculated and the analysis of the filtered sample yieids a post leach surrogate : Fe ratio. Dividing the post-leach surrogate: Fe ratio by the initial surrogate : Fe ratio gives a measure of the relative enrichment (values greater than 1 ) or depletion (values below 1) of the surrogate due to the washing process (Table 5).

Table 5 - Tabulation of post leach surrogate: Fe ratios vs. "as mixed" surrogate : Fe ratios

\begin{tabular}{|l|c|c|c|c|c|}
\hline Element & BiPO4 & TBP & REDOX & PUREX-Al & PUREX-Zr \\
\hline $25^{\circ} \mathrm{C}$ & & & & & \\
\hline Final pH & 5.9 & 5.7 & 5.6 & 5.6 & 5.7 \\
\hline $\mathrm{Al} / \mathrm{Fe}-$-molar & 1.1 & 0 & 15.7 & 12.2 & 0 \\
\hline $\mathrm{Ba}$ & 1.62 & 3.00 & 0.29 & 0.71 & 0.67 \\
\hline $\mathrm{Sr}$ & 0.07 & 0.71 & 0.06 & 0.16 & 0.07 \\
\hline $\mathrm{Pb}$ & 0.74 & 1.43 & 1.10 & 1.03 & 1.49 \\
\hline $\mathrm{Cd}$ & 0.12 & 3.31 & 0.65 & 0.90 & 1.08 \\
\hline $\mathrm{Co}$ & 0.10 & 1.42 & 0.96 & 1.76 & 1.10 \\
\hline $\mathrm{Cr}$ & 0.07 & 0.89 & 1.04 & 1.33 & 0.61 \\
\hline
\end{tabular}




\begin{tabular}{|l|c|c|c|c|c|}
\hline $\mathrm{Nd}$ & 1.52 & 2.74 & 0.99 & 2.14 & 1.49 \\
\hline $\mathrm{Re}$ & $9 \mathrm{E}-4^{*}$ & $2 \mathrm{E}-3$ & $3 \mathrm{E}-3$ & $8 \mathrm{E}-3$ & $3 \mathrm{E}-3$ \\
\hline $\mathrm{C} s$ & $0.0 !$ & $6 \mathrm{E}-3$ & $1 \mathrm{E}-3$ & $4 \mathrm{E}-3$ & $6 \mathrm{E}-6$ \\
\hline $90^{\circ} \mathrm{C}$ & & & & & \\
\hline Final pH & 6.2 & 5.1 & 4.2 & 4.8 & 5.5 \\
\hline $\mathrm{Al} / \mathrm{Fe}-$ molar & 2.0 & 0 & 9.1 & 2.9 & 0 \\
\hline $\mathrm{Ba}$ & 1.37 & 0.85 & 0.49 & 1.74 & 1.30 \\
\hline $\mathrm{Sr}$ & 0.98 & 0.13 & 0.08 & 1.05 & 0.20 \\
\hline $\mathrm{Pb}$ & 0.76 & 1.03 & 1.49 & 0.88 & 1.74 \\
\hline $\mathrm{Cd}$ & 0.97 & 1.12 & 0.61 & 1.12 & 0.41 \\
\hline $\mathrm{Co}$ & 0.83 & 0.84 & 0.75 & 0.95 & 0.88 \\
\hline $\mathrm{Cr}$ & 0.14 & 0.28 & 0.45 & 0.51 & 0.37 \\
\hline $\mathrm{Nd}$ & 1.01 & 2.39 & 0.52 & 1.98 & 1.32 \\
\hline $\mathrm{Re}$ & $5 \mathrm{E}-3$ & $4 \mathrm{E}-3$ & $1 \mathrm{E}-2$ & $4 \mathrm{E}-3$ & $7 \mathrm{E}-3$ \\
\hline $\mathrm{Cs}$ & 0.01 & 0.02 & $5 \mathrm{E}-3$ & $9 \mathrm{E}-3$ & $4 \mathrm{E}-3$ \\
\hline
\end{tabular}

* Notation such as $9 \mathrm{E}-4$ denotes 0.0009

Values greater than roughly 1.15 are particularly problematic and cannot be ascribed to analytic errors. Nor do they probably represent the systematic loss of iron from a sample since, in such instances, all the ratios for a particular sample would be skewed toward high values. Rather, it is likely that they represent a lack of homogeneity in the samples; a nugget effect in which a phase enriched in a particular element was preferentially incorporated into the sample. The balance of the nuggets seemly are associated with, $\mathrm{Ba}, \mathrm{Pb}, \mathrm{Nd}$, and $25^{\circ} \mathrm{C}$ TBP sludges. On the surface the existence of Ba-rich nuggets, and the absence of similar Sr-rich materials, seems problematic. However, this can be explained noting that both Table 4 and Fig. 7 suggest that hydrous iron oxides would scavenging $\mathrm{Sr}$ better than $\mathrm{Ba}$. Thus, Ba would have been more available than $\mathrm{Sr}$ to participate in mineralogic reactions occurring later in the titration at higher $\mathrm{pH}$ values. A likely suspect would be the high $\mathrm{pH}$ nucleation of apatite grains. The existence of clumps of apatite crystals has been verified for both artificial and actual sludges (Fig.8). This may also explain why so many of the nuggets seem to be associated with the TBP sludge. This sludge (Table 1) contains almost an order of magnitude more phosphate than the other mixes, and comparable amounts of calcium. In contrast, the REDOX waste contains no phosphate - so cannot form apatite. This mix has only one nugget, $\mathrm{Pb}$, and TEM studies (Table 2) have recordedthe segregation of a separate $\mathrm{Pb}$-rich phase in some sludges. There are two possible explanations for the Nd nuggets. Nd hydroxide is possible, particularly for the REDOX sludge where the last low $\mathrm{pH}$ treatment liberated detectable $\mathrm{Nd}$ to the soluiton. However, the low $\mathrm{pH}$ treatment failed to liberate detectable $\mathrm{Nd}$ from the other sludges. This anomalous low pH stability, and the fact act that the exceptions to $\mathrm{Nd}$ nugget occurrences were associated with the REDOX sludges, both suggest that in other sludges apatite or $\mathrm{NdPO}_{4}$ plays the dominant role in retaining Nd.
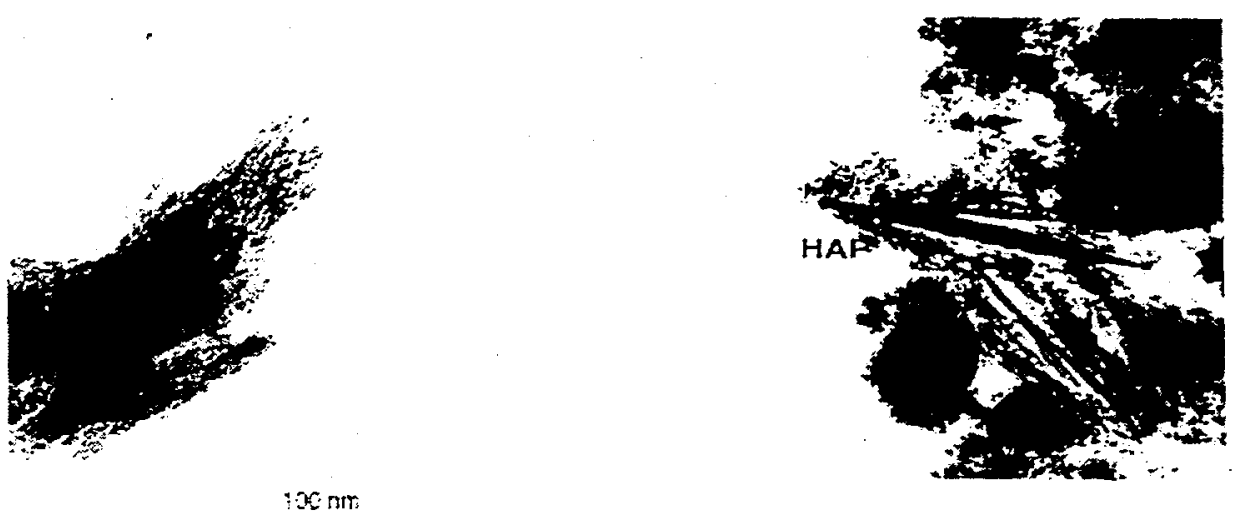

Fig,. 8 Clumps of apatite crystals from artificial sludge (left) and actual sludge from Tank BY-108 (right). 
Once the nugget effect is dispensed with other trends are also apparent in the data set. A relatively large number of the samples in Table 5 show significant $\mathrm{Sr}$ depletion. This is consistent with the $\mathrm{Sr}$ being associated with the $\mathrm{FeOOH}$, and it having been sorbed onto this material at a high pH relative to several other metals in the experiment (Fig. 7). In contrast $\mathrm{Co}, \mathrm{Pb}$ - and presumably $\mathrm{Cd}$, (which sorbs similarly to $\mathrm{Co}(14)$ ), would have sorbed earlier in the neutralization process (e.g. at lower $\mathrm{pH}$ values). Thus, they would have been occluded to a greater degree than $\mathrm{Sr}$ by the later growth and agglomeration of ferrihydrite particles. It follows that a larger proportion of these three early-sorbed elements would remain in the solid sludges as the ionic strength and $\mathrm{pH}$ decreased.

$\mathrm{Cr}$ ratios in unheated samples are generally high and erratic while those in heated sludges are lower and more regular. This simply reflects the fact that in heated samples a significant amount of (insoluble) $\mathrm{Cr}^{+3}$ hydroxide was oxidized to chromate that was not strongly sorbed from the high $\mathrm{pH}$ solutions during the two week aging period.

Finally, the dominant feature of the Re and Cs data (along with Se, which was not detectable in the leachates so no entries appear in Table 5) is that essentially none was retained past the last step of the washing process. Fluid analyses from the last dialysis wash and the acidification step failed to detect significant Re releases. Hence, it is likely that any Re sorbed during the sludge precipitation could be released readily and left during the early dialysis washes. Cs on the other hand, appeared in significant amounts in both the last dialysis wash and the acid treatment fluids. However, this only occurred in experiments associated with Al-bearing sludges. Both the TBP and Zr-Purex sludges yielded rinse solutions that were notably deficient in Cs. Cancrinite zeolites are a ubiquitous Al containing constituent of sludges and seem to be a logical choice as a Cs sink. However, studies directed at understanding the fate of leaked tank fluids determined that freshly precipitated hydrous Al-hydroxides are more likely to retain Cs than cancrinite zeolites (15).

\section{CONCLUSIONS}

This study was undertaken to address two issues: is it possible to develop non-radioactive artificial sludges that resemble those actually found in high level nuclear waste storage tanks and, secondly, what fraction of the radioisotope inventory left in tanks would be mobilized if normal groundwater gain access to the sludge.

At least for the major sludge phases, it is apparent that one can, indeed, mimic what forms in HLW tanks. To demonstrate this it was first necessary to ferret out a considerable amount of detailed process information which was then recast to provide recipes for the main process waste streaams. However, once done was done it became apparent that the procedure for building a reasonable range of artificial sludges is not particularly difficult nor does the finished product have to age for more than a month before it can be used in testing. The one significant defect seems to be the size (but not the phase identity) of the boehmite crystals, which significantly larger in real sludges. This is unlike to change the chemistry of sludges but could impact rheologic test results should these sludge-supernate mixes be used to research the pumping of waste slurries around the tank farms at Hanford and Savannah River.

Although much remains to be learned regarding potential sludge-groundwater interactions, the existing data clearly demonstrates that the complete radionuclide inventory of a decommissioned tank should not be regarded as mobile and, hence, a threat to the surrounding environment. Instead, it appears that a combination of modeling based on well described properties of hydrous iron oxide, solubility limits derived from thermochemical databases and some rudimentary experiments would provide reasonable guidelines in developing performance assessment source terms for a variety of tank decommissioning scenarios. These, in turn, should help significantly in choosing the safest and most cost effective tank closure options. 


\section{REFERENCES}

1. Westrich, H.R.; Krumhansl, J.L., Zhang, P.-C; Anderson, H.L., Molecke, M.A., Ho, C., Dwyer, B.P., and McKeen, G., 1998, Stabilization of in-tank residual wastes and external-tank soil contamination for the Hanford Tank Closure Program: Appllications to the AX Tank Farm, SAND98-2445, 112 p.

2. Johnson, L.H., and Shoesmith, D.W., 1988, in Lutze, W. and Ewing, R.C., Radioactive waste forms for the future, C.11, table 1, p. 61 .

3. Kupfer, M.J . et al. (14 contributors), 1997, Standards inventories of chemicals and radionuclides in Hanford Site tank Wastes, HNF-SD-WM-TI-740.

4. Agnew, S.F., 1996, Hanford tank chemical and radionuclide inventories: HDW Model Rev. 4., LA-UR96-3860.

5. Colton, N.G., 1994, Sludge pretreatment chemistry evaluation: Enhanced sludge washing separation factors, TWRSPP-94-053.

6. Hsu and Ritter, 1996, Treatment of High-Level Radioactive Waste, Nuclear Technology, v. 116, p. 198, Table I.

7. Fowler, J.R., 1982, Waste sludge compositions at the Savannah River Plant, 1982, American Nuclear Society Transactions, v. 41, p. 159-160.

8. Norton, M.V., and Torres-Ayala, F., 1994, Summary letter report: Laboratory testing in-tank sludge washing, PNL-10153, p. 3-4.

9. Baes, C.F., and Mesmer, R.F., 1976, The hydrolysis of cations, John Wiley \& Sons, 489 pp.

10. Fowler, J.R, and Wallice, Dec.2, 1980, R.M., Memorandum: CRC Zeolite in SRP Waste, Technical

Division, Savannah River Laboratory, DPST-80-488.

11. Cornell, R.M., and Schwertmann, 1996, The iron oxides: structure, properties, reactions, occurrence, and uses, VCH Verlagsgesellschaft, mbH Waldhiem, $570 \mathrm{pp}$

12. Silva, R.J., and Nitsche, H., 1995, Radiochimica Acta 70/71, p. 377-396.

13. Bethke, C.M., 1966, Geochemical reaction modeling, concepts and applications, Oxford University Press, 397 pp.

14.Dzombak, D.A., and Morel, F.M.M., 1990, Surface complexation modeling - hydrous ferric oxide, John Siley and Sons p. 299-306.

15. Nyman, M., Krumhansl, J.L., Zhang P.-C., Anderson, H.L., and Nenoff, T.N., 1999, Chemical evolution of leaked high-level liquid wastes in Hanford soil - DSSF interactions, Scientific Basis for Nuclear Waste Management XXIII, Materials Research Society (in press).

This work sponsored by Sandia National Laboratories, Albuquerque, New Mexico, USA, 87185.

Sandia is a multiprogram laboratory operated by Sandia Corporation, a Lockheed Martin Company, for the U.S. Department of Energy [DOE] under contract: DE-AC04-94AL8500. 


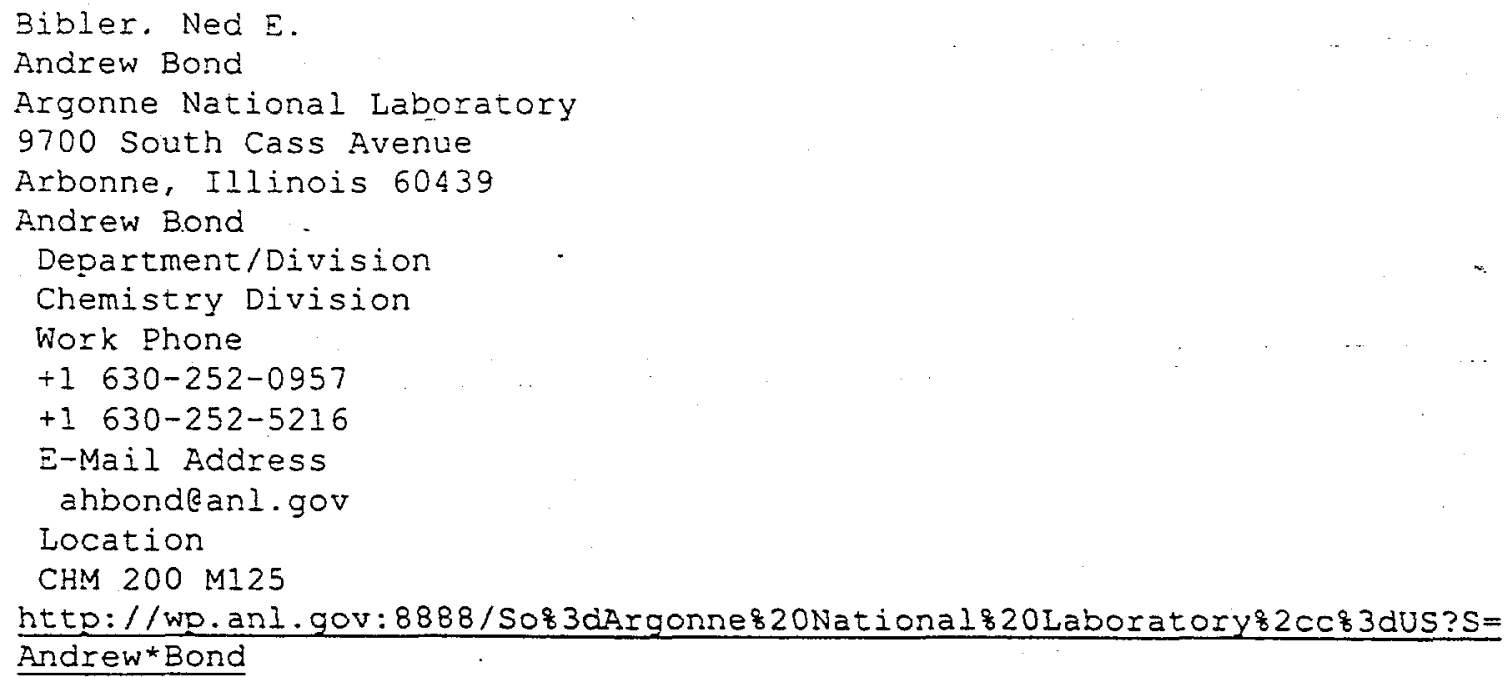

